\title{
Functional Properties of Lupinus angustifolius Seed Protein Isolates
}

\author{
Antonio Hilario Lara-Rivera, ${ }^{1}$ Pedro García-Alamilla, ${ }^{2}$ Laura Mercedes Lagunes-Gálvez, ${ }^{2}$ \\ Ramón Rodríguez Macias, ${ }^{1}$ Pedro M. García López, ${ }^{1}$ and Juan Francisco Zamora Natera ${ }^{1}$ \\ ${ }^{1}$ Centro Universitario de Ciencias Biológicas y Agropecuarias, Departamento de Botánica y Zoología, Universidad de Guadalajara, \\ 45110 Zapopan, JAL, Mexico \\ ${ }^{2}$ División Académica de Ciencias Agropecuarias, Universidad Juárez Autónoma de Tabasco, Carretera Villahermosa-Teapa Km. 25, \\ Ra. La Huasteca, 2 da Secc., 86298 Centro, TAB, Mexico \\ Correspondence should be addressed to Pedro García-Alamilla; pedro.garciaa@ujat.mx
}

Received 13 June 2017; Revised 7 October 2017; Accepted 13 November 2017; Published 7 December 2017

Academic Editor: Susana Fiszman

Copyright (C) 2017 Antonio Hilario Lara-Rivera et al. This is an open access article distributed under the Creative Commons Attribution License, which permits unrestricted use, distribution, and reproduction in any medium, provided the original work is properly cited.

\begin{abstract}
Protein isolates prepared by alkaline solubilization followed by isoelectric precipitation and freeze-drying from six varieties of Lupinus angustifolius (Haags Blaue, Sonate, Probor, Borlu, Boregine, and Boruta) grown in Mexico were evaluated for functional properties: nitrogen solubility, water-holding capacity (WHC), oil holding capacity (OHC), emulsion activity index (EAI), emulsion stability index (ESI), foaming capacity (FC), foam stability (FS), and gelling minimum concentration (GMC). The nitrogen solubility values, WHC, OHC, and FC did not show significant differences between the protein isolates. The solubility of the isolates was minimal at $\mathrm{pH}$ of 4.0 and 5.0 while the regions of maximum solubility were found at $\mathrm{pH}$ of 2.0 and 10.0. There were significant differences in EAI and ESI depending on the varieties used. The isolates of the Boregine and Borlu varieties showed the highest EAI with 29.3 and $28.3 \mathrm{~m}^{2} \mathrm{~g}^{-1}$, respectively, while the lowest index was recorded in the isolate obtained from the Sonate variety $\left(24.6 \mathrm{~m}^{2} \mathrm{~g}^{-1}\right)$. Like solubility, these indices also increased at both extremes of $\mathrm{pH}$ evaluated; both properties were minimal in the isoelectric $\mathrm{pH}$ range (4.0 to 5.0 ).
\end{abstract}

\section{Introduction}

Legume seeds represent an important and economical source of protein for human and animal feeding [1]. Its amino acid composition is generally adequate; however, some species contain deficient amounts of some amino acids [2]. Soybeans worldwide represent the main source of protein; nevertheless, the food industry is in the search for new sources of vegetable proteins of good nutritional quality and functional characteristics superior or equal to soybean proteins $[1,2]$. Among the species most likely to compete with soybean proteins are legumes of the genus Lupinus [3, 4]. Historical antecedents indicate that different cultures of the Mediterranean and South America practiced for several years the cultivation of some species of the genus Lupinus to include them in their diet like Lupinus albus, L. luteus, L. angustifolius, and L. mutabilis. $[5,6]$. Due to its high protein content and to the new varieties with low alkaloid content, the cultivation of these legumes has spread to other regions of the world for use in animal and human nutrition [7-9]. In addition, Lupinus are more adaptable to regions with low fertility soils and mild or very cold winters compared to soybean cultivation [10]. The seeds of these species represent a functional food ingredient because their proteins are related to the prevention of cardiovascular diseases, and it had been found that their proteins (conglutins) reduce blood glucose in hyperglycemic rats $[11,12]$. In this way, obtaining protein isolates of Lupinus by isoelectric precipitation is an alternative for the commercial production of food ingredients. At present, the food industry has shown a growing interest in protein isolates, due to their functional properties such as water absorption, oil absorption, emulsification, foam formation, and gelation. These properties are essential to determine the possible uses of these as food ingredients. Functional properties provide 
information on how a particular ingredient would behave in a food matrix, play a prominent role during the preparation, processing, and storage of food, and, in turn, correlate with sensory properties. These properties could be considered as a result of different conformational changes or interactions between food components, such as interactions between proteins, proteins, and polysaccharides, lipids, phenolic compounds, or phytic acid [13]. Furthermore, they constitute the functional base of diverse products mainly of low protein content and high fat content. On the other hand, legumes are source of beneficial compounds that have a protective effect on the development of various diseases [14]. Therefore, the objective of the present research work was to determine the functional properties of protein isolates of six varieties obtained from Lupinus angustifolius cultivated in the state of Jalisco, Mexico.

\section{Material and Methods}

2.1. Vegetable Materials. Seeds of six varieties of L. angustifolius (Haags Blaue, Sonate, Probor, Borlu, Boregine, and Boruta) were used which were provided by the German company Saatzucht Steinach $\mathrm{GmbH}$ dedicated to genetic improvement. These seeds were sown and cultivated during the fall/winter period of 2014/2015 under irrigated conditions on agricultural soils of the University Center of Biological and Agricultural Sciences of the University of Guadalajara in Zapopan, Jalisco, Mexico. This site is located at the geographical coordinates $20^{\circ} 44^{\prime} 47^{\prime \prime} \mathrm{N}$ and $103^{\circ} 30^{\prime} 43^{\prime \prime} \mathrm{W}$ at an altitude of $1,523 \mathrm{~m}$. It is characterized by a humid temperate climate with rains in summer, with precipitations ranging from 700 to $1400 \mathrm{~mm}$ per year and an annual average temperature of 12.0 to $18.0^{\circ} \mathrm{C}$, with the presence of frost. After conventional land preparation with a moldboard plow and a disk harrow, seeding was performed manually under an experimental randomized block design, with four replicates.

\subsection{Proximate Composition and Preparation of Protein Iso-} lates. After harvesting on the order of $50 \mathrm{~kg}$ of seeds, one batch of $1 \mathrm{~kg}$ each variety was separately ground with a knife mill $\left(\mathrm{IKA}^{\circledR}\right.$ ) until flour with a particle size of $2 \mathrm{~mm}$ was obtained. Every variety was subjected to triplicate a proximal chemical analysis according to the techniques described in AOAC (2000): moisture content (925.09), crude fat (920.30), crude protein (979.09), ash (923.03), crude fiber (962.09), and carbohydrate content [15]. The flour was subjected to a degreasing process by Soxhlet extraction, using hexane as solvent [16]. The defatted sample (100 g) was used to obtain the protein isolates.

The protein isolate was obtained using the isoelectric precipitation method [17]. A dispersion of $100 \mathrm{gL}^{-1}$ in $\mathrm{Na}_{2} \mathrm{SO}_{3}(0.025 \%)$ was prepared and adjusted to $\mathrm{pH}$ of 9.0 using $\mathrm{NaOH}(1 \mathrm{~N})$. Immediately it was stirred for one hour at room temperature $\left(25^{\circ} \mathrm{C}\right)$ and centrifuged at $10,976 \times \mathrm{g}$. (HERMLE Labortechnik GmbH, Z 326, Germany) for $10 \mathrm{~min}$. The supernatant was acidified to $\mathrm{pH}$ of 4.5 using $\mathrm{HCl}(1 \mathrm{~N})$. This was subjected to centrifugation at $10,976 \times \mathrm{g}$ for $10 \mathrm{~min}$ at $4^{\circ} \mathrm{C}$, recovering the precipitate. A washing process with distilled water was applied to the precipitate and $\mathrm{NaOH}$
$(1 \mathrm{~N})$ was used to bring it to a $\mathrm{pH}$ of 7 . The precipitate was lyophilized and stored at $4^{\circ} \mathrm{C}$. The protein isolates obtained from the seeds of the six varieties were analyzed in triplicate for all functional properties.

\subsection{Functional Properties}

2.3.1. Solubility. The solubility of the protein isolates was evaluated according to the methodology proposed by Ogunwolu et al. [18] and Liu et al. [19] with slight modifications. Each isolate was prepared in a $0.1 \% \mathrm{w} / \mathrm{v}$ suspension in $10 \mathrm{~mL}$ of distilled water. The $\mathrm{pH}$ was adjusted in a range of 2.0-10.0 using $\mathrm{NaOH}(0.1 \mathrm{~N})$ or $\mathrm{HCl}(0.1 \mathrm{~N})$. The suspension was stirred for $30 \mathrm{~min}$ on an orbital shaker (Thermo Fisher Scientific, Multipurpose rotator, 2346, China). Subsequently, it was centrifuged for $10 \mathrm{~min}$ at 10,976 $\times \mathrm{g}$ (HERMLE Labortechnik GmbH, Z 326, Germany). The protein content in the supernatant was determined by the Bradford method. The standard curve was made from bovine serum albumin (BSA) and the absorbance of the samples was measured at $595 \mathrm{~nm}$ on a spectrophotometer (Thermo Fisher Scientific, G10S UvVis, China). The solubility of the protein was calculated by the following equation:

$$
\text { Solubility }=\frac{\text { protein in supernatant }(\mathrm{g})}{\text { protein in sample }(\mathrm{g})} \times 100 \text {. }
$$

2.3.2. Water-Holding Capacity (WHC). The WHC was evaluated by the method of Chau et al. [20] with slight modifications. Samples of protein isolates $(0.5 \mathrm{~g})$ were dispersed in $5 \mathrm{~mL}$ of distilled water and stirred for $24 \mathrm{~h}$. After this time, the centrifugation for $30 \mathrm{~min}$ at $1474 \mathrm{~g}$ (HERMLE Labortechnik GmbH, Z 326, Germany) was carried out. The volume of the supernatant was measured after centrifugation. The difference between the initial volume of water and the volume recovered after centrifugation determines the WHC expressed as milliliters of water by one gram of sample $\left(\mathrm{mL} \mathrm{g}^{-1}\right)$.

The WHC was determined using the following equation:

$$
\mathrm{WHC}\left(\mathrm{mL} \mathrm{g}^{-1}\right)=\frac{V_{i}-V_{s}}{W_{m}},
$$

where $V_{i}$ is the initial volume of distilled water $(\mathrm{mL}) ; V_{s}$ is the volume of the supernatant $(\mathrm{mL})$, and $W_{m}$ is the weight of the sample (g).

2.3.3. Oil Holding Capacity (OHC). The $\mathrm{OHC}$ was evaluated by the method of Chau et al. [20] with slight modifications. $0.5 \mathrm{~g}$ of the protein isolates that were obtained was added $5 \mathrm{~mL}$ of canola oil contained in a $50 \mathrm{ml}$ centrifuge tube, which was stirred for $30 \mathrm{~min}$ by magnetic stirring. Then, it is centrifuged at 1,474 g (HERMLE Labortechnik GmbH, Z 326, Germany) for 30 minutes. After centrifugation, the volume of the supernatant is measured. The difference between the initial volume of oil and the volume recovered corresponds to the $\mathrm{OHC}$ expressed in $\mathrm{mL} \mathrm{g}^{-1}$ of protein isolates. 
TABLE 1: Chemical composition of seed flour of varieties of Lupinus angustifolius cultivated in Mexico (\% dry basis).

\begin{tabular}{lcccccc}
\hline Variety & Moisture & Protein & Ash & Fat & Crude fiber & Carbohydrates \\
\hline Haags Blaue & $3.59^{\mathrm{b}}$ & $32.33^{\mathrm{b}}$ & $3.50^{\mathrm{a}}$ & $4.40^{\mathrm{b}}$ & $8.05^{\mathrm{c}}$ & $48.13^{\mathrm{b}}$ \\
Boregine & $3.65^{\mathrm{b}}$ & $29.23^{\mathrm{c}}$ & $3.34^{\mathrm{a}}$ & $3.88^{\mathrm{c}}$ & $8.22^{\mathrm{c}}$ & $51.68^{\mathrm{a}}$ \\
Borlu & $4.38^{\mathrm{a}}$ & $33.42^{\mathrm{b}}$ & $3.13^{\mathrm{a}}$ & $4.17^{\mathrm{b}}$ & $10.06^{\mathrm{b}}$ & $44.84^{\mathrm{b}}$ \\
Probor & $3.84^{\mathrm{b}}$ & $36.61^{\mathrm{a}}$ & $3.25^{\mathrm{a}}$ & $4.20^{\mathrm{b}}$ & $9.86^{\mathrm{ab}}$ & $42.24^{\mathrm{b}}$ \\
Sonate & $3.79^{\mathrm{b}}$ & $32.50^{\mathrm{b}}$ & $3.51^{\mathrm{a}}$ & $5.29^{\mathrm{a}}$ & $12.49^{\mathrm{a}}$ & $4.42^{\mathrm{a}}$ \\
Boruta & $3.68^{\mathrm{b}}$ & $28.40^{\mathrm{c}}$ & $3.43^{\mathrm{a}}$ & $5.31^{\mathrm{a}}$ & $15.12^{\mathrm{a}}$ & $44.06^{\mathrm{a}}$ \\
\hline
\end{tabular}

Different letters in rows indicate significant differences $(P<0.05)$.

The $\mathrm{OHC}$ was determined by the following equation:

$$
\mathrm{OHC}\left(\mathrm{mLg}^{-1}\right)=\frac{V_{i}-V_{s}}{W_{m}},
$$

where $V_{i}$ is the initial volume $(\mathrm{mL}) ; V_{s}$ is the volume of the supernatant $(\mathrm{mL})$; and $W_{m}$ is the weight of the sample $(\mathrm{g})$.

\subsubsection{Emulsion Activity Index (EAI) and Emulsion Stability} Index (ESI). EAI and ESI were determined using the method described by Zheng et al. [21] with slight modifications, which consisted of mixing $10 \mathrm{mg}$ of the protein isolates with $10 \mathrm{~mL}$ of distilled water together with $3.33 \mathrm{~mL}$ of canola oil. The $\mathrm{pH}$ of the dispersion was adjusted in a range of 2.0-10.0 by the addition of $\mathrm{HCl}(0.1 \mathrm{~N})$ or $\mathrm{NaOH}(0.1 \mathrm{~N})$ according to the case. Subsequently, the mixtures were homogenized on a vortex stirrer (IKA Mixing, Model MS1) for $1 \mathrm{~min}$ at $2,500 \mathrm{rpm}$. Then, a $5 \mathrm{~mL}$ aliquot of each emulsion formed was mixed with $5 \mathrm{~mL}$ of $0.1 \%$ sodium dodecylsulfate. The samples were analyzed on a spectrophotometer (Thermo Fisher Scientific, G10S Uv-Vis, China) and the absorbance was read at $500 \mathrm{~nm}$.

The EAI was determined by the following equation:

$$
\text { EAI }\left(\mathrm{m}^{2} \mathrm{~g}^{-1}\right)=\frac{2 \times 2.303 \times A_{0} \times \mathrm{DF}}{c \times \emptyset \times 1-\theta}
$$

where $A_{0}$ is the zero minute absorbance; DF is the dilution factor $(100) ; c$ is the initial protein concentration $(0.1 \mathrm{~g}$ $\left.100 \mathrm{~mL}^{-1}\right)$; $\emptyset$ is optical path $(0.01 \mathrm{~m})$; and $\theta$ is the fraction of oil $(\mathrm{v} / \mathrm{v})$ used to form the emulsion $(0.25)$. After reading the absorbances in zero time, the emulsions were allowed to stand at room temperature $\left(25^{\circ} \mathrm{C}\right)$ for 10 minutes $\left(A_{10}\right)$. The absorbance of emulsions was obtained again, and the emulsion stability index (ESI) was calculated with the following equation:

$$
\mathrm{ESI}(\min )=\frac{A_{0}}{A_{0}-A_{10}} \times 10
$$

2.3.5. Foaming Capacity (FC) and Foam Stability (FS). FC and FS were determined following the method described by Cheung and Chau [22]. $0.5 \mathrm{~g}$ of protein isolates was mixed with $25 \mathrm{~mL}$ of distilled water adjusted to $\mathrm{pH}$ 7, by the addition of $\mathrm{HCl}(0.1 \mathrm{~N})$ or $\mathrm{NaOH}(0.1 \mathrm{~N})$. They were then shaken in a Oster (Sunbeam Mexicana, S.A de C.V, Model: BLSTEP7808W-013, Mexico) at the "lowest" speed (mode 1 of 10) for $5 \mathrm{~min}$. The mixture was transferred to a graduated cylinder $(50 \mathrm{~mL})$. After 30 seconds, the initial foam volume was measured as well as after 5, 10, 15, 30, 60, and 120 minutes.

The foaming capacity was determined by the following equation:

$$
\mathrm{FC}(\%)=\frac{\mathrm{VF} 30^{\prime \prime}}{\mathrm{VF} 0} \times 100,
$$

where VF30" is the volume of foam measured after 30 seconds of rest after the sample has been shaken; VF0 is the volume of foam measured after agitation.

The FS was determined using the following equation:

$$
\text { FS }(\%)=\frac{V F t x^{\prime \prime}}{\text { VF0 }} \times 100,
$$

where VFt $x$ " is the foam volume after standing for $5,10,15$, 30,60 , and $120 \mathrm{~min}$.

2.3.6. Gelling Minimal Concentration (GMC). The GMC of the protein isolates was determined according to the method described by Cheung and Chau [22]. Suspensions of the protein isolates $(50 \mathrm{~mL})$ were prepared at a concentration of $4-20 \%(\mathrm{w} / \mathrm{v})$ in distilled water, and the $\mathrm{pH}$ was adjusted to 7 by adding $\mathrm{HCl}(0.1 \mathrm{~N})$ or $\mathrm{NaOH}(0.1 \mathrm{~N})$. The suspensions were poured in $50 \mathrm{~mL}$ falcon tubes, which were placed in a vessel with water at $100^{\circ} \mathrm{C}$ for $1 \mathrm{~h}$. Immediately thereafter, they were maintained at $4^{\circ} \mathrm{C}$ for $2 \mathrm{~h}$. After the cooling time, the tubes were inverted to determine the degree of displacement of the suspensions through the walls of the tube. The absence of displacement at the different concentrations was considered as the GMC in the isolates.

2.4. Statistical Analysis. The results obtained were subjected to analyses of variance (ANOVA) using the Statgraphics Plus software (v.4.1). Tukey's test was used to determine the significance of differences between treatments, with $P<0.05$ taken to indicate a significant difference.

\section{Results and Discussion}

3.1. Chemical Composition of Lupine Seed Flour and Protein Concentration of Isolates. Table 1 shows the results of the chemical analysis of the different flours of lupine seeds (Haags Blaue, Sonate, Probor, Borlu, Boregine, and Boruta). The results showed that the main components of the seeds 
are carbohydrates and proteins (28.40-36.61\%), of which the high content is similar to that of soybean seeds [23]. Significant differences (Table 1) were found between Probor and the other varieties, which showed the highest protein content $(36.61 \%)$. In relation to the ash content, no significant differences $(P>0.05)$ were found. These values were lower than those reported for L. luteus and similar to that of $L$. angustifolius [24]. The results of the crude fat determination showed lower values than those reported for soybean [25]. The varieties Haags Blaue (4.40), Boregine (3.88\%), and Boruta $(5.31 \%)$ showed significant difference $(P<0.05)$ among themselves. The results show that the fiber content varied from 8.05 to $15.12 \%$ in the flours of lupine seeds, which are similar to those of other legumes such as peas, beans, and lentils (13.6-28.9\%) [26-28]. Regarding the carbohydrates content, the values found ranged from 42.24 to $51.68 \%$, similar to those reported to peas, beans, and lentils [26]. The moisture values of the varieties of the present work were inferior to other legumes such as common bean (10\%) [28] and higher to the Pardina lentil (4\%) [29].

The final concentrations of proteins of Haags Blaue, Boregine, Borlu, Probor, Sonate, and Boruta obtained were $89.33 \%, 89.23 \%, 89.42 \%, 90.61 \%, 89.50 \%$, and $88.40 \%$ respectively. It has been observed that both the purity and the amount of protein recovered are affected by the characteristics of the seeds, extraction time and temperature, and the relation between the flour with the solvent and the $\mathrm{pH}$ at which protein precipitation takes place [30].

\subsection{Functional Properties}

3.2.1. Solubility of Protein. The solubility of protein isolates provides important information about their possible technological applications [31]. According to Horax et al. [32], the solubility of the protein at different $\mathrm{pH}$ values can serve as a useful indicator of the efficiency or performance of protein isolates in food and also of the degree of protein denaturation due to heat or chemical treatment. Figure 1 shows the variations of the solubility percentage of the protein in a range from $\mathrm{pH} 2.0$ to 10.0, in which a similar behavior can be observed in all isolates. The results at $\mathrm{pH} 4$ and 5 showed a sharp decrease in the solubility for all six isolates of Lupinus as reported Chau et al. [33]. At $\mathrm{pH} 2$ about $98-99 \%$ of the protein isolates were soluble, and about $98-99 \%$ were soluble at $\mathrm{pH}$ of 9 and 10, respectively, with no significant differences between them; meanwhile the minimum solubility percentages (12\%) were recorded at $\mathrm{pH}$ of 4.0 and 5.0 as the isoelectric point of proteins. At this $\mathrm{pH}$, the electrostatic intermolecular repulsion and its ionic hydration at this point are minimal, which causes precipitation of the proteins. The solubility pattern recorded in this study is similar to that reported in isolates obtained from L. albus and L. spp. where the minimum solubility value of the protein was less than $1 \%$ at $\mathrm{pH} 4.0$ [34]. However, El-Adawy et al. [35] reported a different behavior in Lupinus termis and Lupinus albus, since the minimum solubility value of the proteins (14 to $18 \%$ ) was found in a range of $\mathrm{pH}$ of 4.0-5.0. On the other hand, Lqari et al. [36] evaluated the solubility of the protein expressed as a percentage of soluble nitrogen at $\mathrm{pH}$ values 3.8-5.0 in a

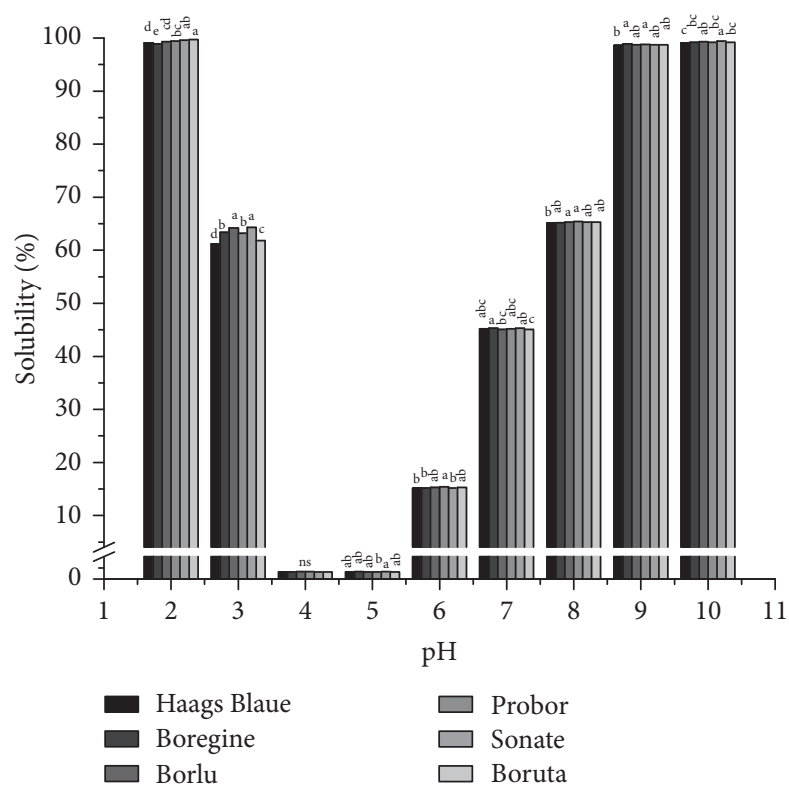

FIGURE 1: Effect of $\mathrm{pH}$ on the solubility of six varieties of Lupinus angustifolius protein isolates. Different letters indicate significant differences among varieties at $P<0.05$; ns indicates nonsignificance $(P>0.05)$.

L. angustifolius isolate; the solubility of the protein was min$\mathrm{imal}(22.5 \%)$ at $\mathrm{pH}$ 4.3. In other legumes such as pea (Pisum sativum), bean (Vicia faba), and soybean (Glycine max), the lowest solubility percentage of the protein (1-10\%) was found in $\mathrm{pH}$ values of 4.0-5.0 [37]. In a similar investigation of the present study but with different varieties of chickpea, Kaur and Singh [38] and Withana-Gamage et al. [39] found that protein solubility was minimal $(2-6 \%)$ in a $\mathrm{pH}$ range of 4.0-4.5. The results showed good solubility in both the acidic and alkaline $\mathrm{pH}$ regions which was an important characteristic in food formulations.

3.2.2. Water-Holding Capacity (WHC) and Oil Holding Capacity $(\mathrm{OHC})$. Table 2 shows the WHC and $\mathrm{OHC}$ of protein isolates of Lupinus. The maximum values of water absorption were recorded in the isolates obtained from the Haags Blaue and Boruta varieties with 2.98 and $2.95 \mathrm{~mL} \mathrm{~g}^{-1}$, respectively. Haags Blaue, Probor, Sonate, and Boruta did not show significant differences $(P>0.05)$. In general, the WHC values obtained in this study are considered high and are higher than those recorded in protein isolates of $L$. campestris, L. albus, L. splendens, L. termis, and L. angustifolius $[34,36,40]$ and similar (Mean of $2.46 \mathrm{~mL} \mathrm{~g}^{-1}$ ) to those found in commercial soy protein isolates (Supro 670). This property is related to the ability of proteins to hydrate [18], and it is important in food systems due to their effects on the taste and texture of food [41]. The water retention is a function of isolate obtention method, where alkaline conditions have an influence in the protein denaturation, its solubility, and the lower WHC [42].

The OHC did not show significant differences $(P>0.05)$ between the isolates (Table 2). The mean value of $\mathrm{OHC}$ in the six isolates was $2.63 \mathrm{~mL} \mathrm{~g}^{-1}$, which is higher than that 
TABLE 2: Functional properties of protein isolates obtained from seeds of varieties of Lupinus angustifolius cultivated in Mexico.

\begin{tabular}{|c|c|c|c|c|c|c|}
\hline Variety & Haags Blaue & Boregine & Borlu & Probor & Sonate & Boruta \\
\hline Solubility (\%) & $0.31^{\mathrm{a}}$ & $0.33^{\mathrm{a}}$ & $0.31^{\mathrm{a}}$ & $0.34^{\mathrm{a}}$ & $0.31^{\mathrm{a}}$ & $0.32^{\mathrm{a}}$ \\
\hline $\mathrm{WHC}\left(\mathrm{mL} \mathrm{g}^{-1}\right)$ & $2.98^{\mathrm{a}}$ & $2.84^{\mathrm{b}}$ & $2.81^{\mathrm{b}}$ & $2.91^{\mathrm{a}}$ & $2.93^{\mathrm{a}}$ & $2.95^{\mathrm{a}}$ \\
\hline $\mathrm{OHC}\left(\mathrm{mL} \mathrm{g}^{-1}\right)$ & $2.65^{\mathrm{a}}$ & $2.64^{\mathrm{a}}$ & $2.61^{\mathrm{a}}$ & $2.62^{\mathrm{a}}$ & $2.63^{\mathrm{a}}$ & $2.65^{\mathrm{a}}$ \\
\hline $\operatorname{EAI}\left(\mathrm{m}^{2} \mathrm{~g}^{-1}\right)$ & $27.1^{\mathrm{b}}$ & $29.3^{\mathrm{a}}$ & $28.3^{\mathrm{a}}$ & $27.5^{\mathrm{b}}$ & $26.4^{\mathrm{b}}$ & $27.2^{\mathrm{b}}$ \\
\hline ESI (min) & $14.7^{\mathrm{a}}$ & $12.4^{\mathrm{b}}$ & $11.9^{c}$ & $14.9^{\mathrm{a}}$ & $13.1^{\mathrm{b}}$ & $12.9^{\mathrm{b}}$ \\
\hline FC (\%) & $116.3^{\mathrm{a}}$ & $116.6^{\mathrm{a}}$ & $116.5^{\mathrm{a}}$ & $116.7^{\mathrm{a}}$ & $116.4^{\mathrm{a}}$ & $116.8^{\mathrm{a}}$ \\
\hline FS (\%) & $92.8^{\mathrm{ab}}$ & $93.4^{\mathrm{a}}$ & $91.9^{c}$ & $92.6^{\mathrm{b}}$ & $92.4^{\mathrm{b}}$ & $93.9^{\mathrm{a}}$ \\
\hline GMC (\%) & $11.00^{\mathrm{b}}$ & $10.00^{c}$ & $11.00^{\mathrm{b}}$ & $12.00^{\mathrm{a}}$ & $11.00^{\mathrm{b}}$ & $11.00^{\mathrm{b}}$ \\
\hline
\end{tabular}

Different letters in the same row indicate significant differences $(P<0.05)$. WHC: water holding capacity; OHC: oil holding capacity; EAI: emulsion activity index; ESI: emulsion stability index; FC: foaming capacity; FS: foam stability index; GMC: gelling minimum concentration.

recorded in an isolate of L. campestris $\left(1.7 \mathrm{~mL} \mathrm{~g}^{-1}\right)$, but lower than that obtained in isolates of $L$. albus and L. splendens with 2.85 and $4.63 \mathrm{~mL} \mathrm{~g}^{-1}$, respectively [34, 40]. Lqari et al. [36] in other leguminous isolates such as peas (Pisum sativum), bean (Vicia faba), and soybean (Glycine max) also reported OHC values lower $\left(1.2,1.6\right.$, and $1.1 \mathrm{~mL} \mathrm{~g}^{-1}$ protein) than those recorded in the isolates obtained and characterized in this study.

In general, as reported by Carvalho et al. [42], the OHC obtained in this study shows that Lupinus protein isolates possess well balanced proportions of externally oriented hydrophilic and hydrophobic groups; being able to reduce the interfacial tension in an emulsion system, they are very important in such as applications as in processing meat bases products. The values of WHC and OHC for these protein isolates that can be considered high in relation to others protein isolates used as ingredients in the preparation of cold meats, especially for sausages, are determining properties to develop a food of acceptable quality [18].

\subsubsection{Emulsion Activity Index (EAI) and Emulsion Stability} Index (ESI). Significant differences $(P<0.05)$ were observed in both indexes according to the L. angustifolius varieties used (Table 2). The isolates obtained from the Boregine and Borlu varieties showed the highest EAI with 29.3 and $28.3 \mathrm{~m}^{2} \mathrm{~g}^{-1}$, respectively, while the lowest was recorded in the isolate obtained from the Sonate variety $\left(26.4 \mathrm{~m}^{2} \mathrm{~g}^{-1}\right)$, while, in the ESI, the highest values were 14.9 and $14.7 \mathrm{~min}$ in the Probor and Haags Blaue isolates, respectively, and while the lower index was found in the protein isolate obtained from the Borlu variety $(11.9 \mathrm{~min})(P<0.05)$.

The profiles of emulsifying activities (EAI and ESI) against $\mathrm{pH}$ are shown in Figures 2 and 3. The profiles of EAI and ESI are similar to solubility; these properties also increased at both $\mathrm{pH}$ extremes evaluated and were minimal in the isoelectric $\mathrm{pH}$ range (4.0 to 5.0). The profile of the emulsion properties as a function of $\mathrm{pH}$ for the different protein isolates studied was similar to that presented by the Indian and soybean protein isolates [18], as well as $L$. campestris isolates [40]. The slight differences of the emulsion properties in the studied varieties can be due to the different level of solubilized proteins, which can influence the EAI and ESI by modifying the balance of Van der Waals attractive

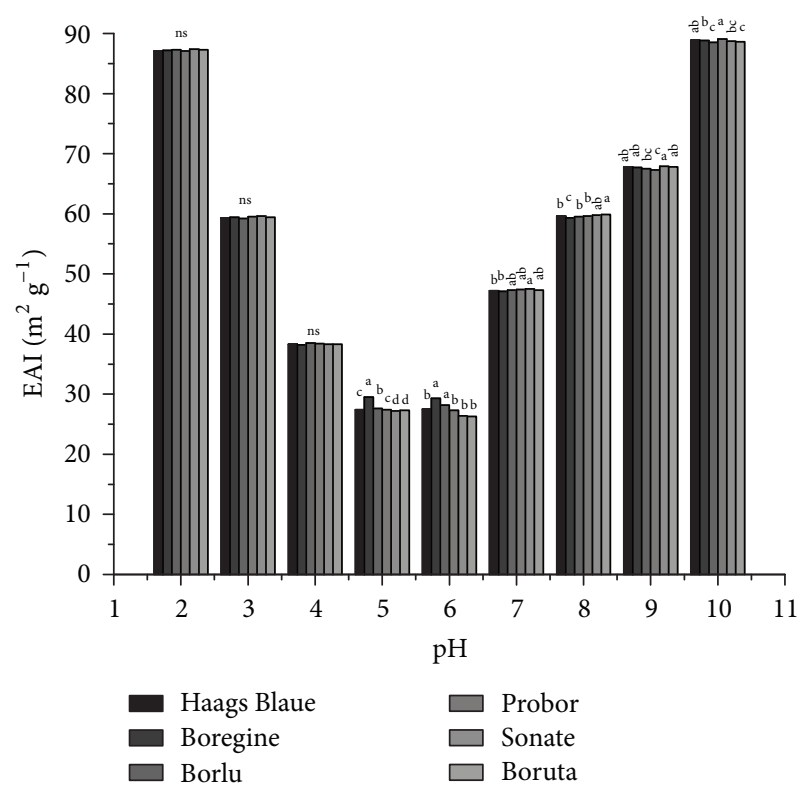

FIGURE 2: Effect of $\mathrm{pH}$ on the emulsion activity index (EAI) of six varieties of Lupinus angustifolius protein isolates. Different letters indicate significant differences among varieties at $P<0.05$; ns indicates nonsignificance $(P>0.05)$.

and repulsive electrostatic forces; a more soluble protein produces a rapid migration to the oil-water interface, thus favoring the formation and stability of emulsions [43]. In general, the profiles of EAI (Figure 2) and ESI (Figure 3) presented variations similar to those reported in other isolates or concentrates, which are defined as a V shape pattern, indicating changes of the hydrophilic-lipophilic balance of the proteins in the $\mathrm{pH}$ gradient from 2 to 10 . The result confirms the relationship between emulsifying and solubility properties of proteins. However, the results shown in this study and similar ones should be validated with other factors that may influence the emulsification properties, among them, droplet size, net charge, interfacial tension, viscosity, and protein conformation [42,44]. Temperature is also a key factor affecting emulsifying properties of proteins. During the present study, the conditions used were $25^{\circ} \mathrm{C}$, while other 


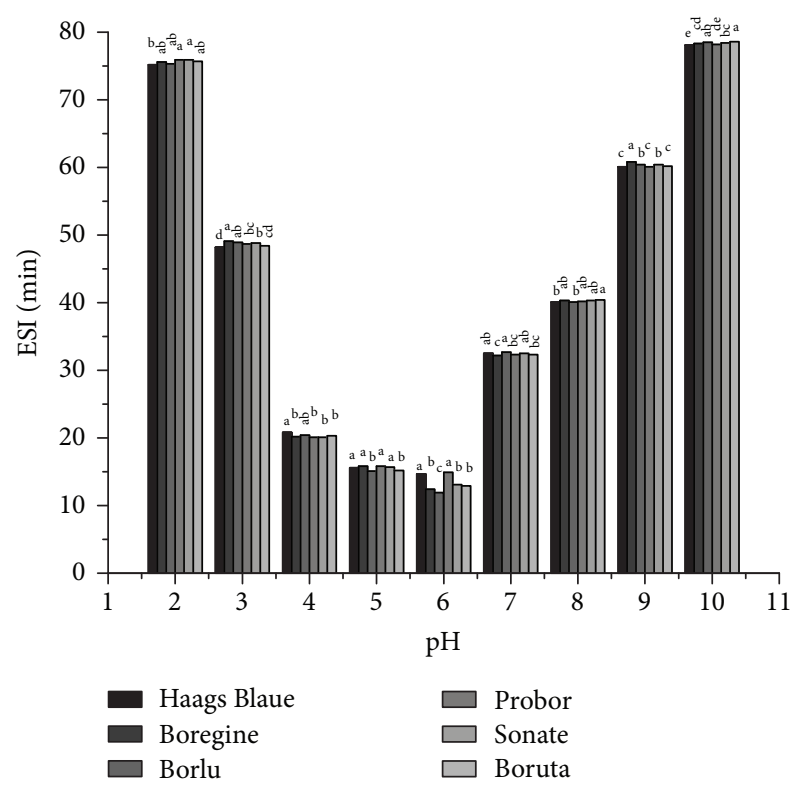

Figure 3: Effect of $\mathrm{pH}$ on the emulsion stability index (ESI) of six varieties of Lupinus angustifolius protein isolates. Different letters indicate significant differences among varieties at $P<0.05$.

methodologies for the determination of emulsification report $80^{\circ} \mathrm{C}[45]$.

3.2.4. Foaming Capacity (FC) and Foam Stability (FS). The protein isolates showed similar FC values, between 116.3 and $116.8 \%$ (Table 2), without significant differences $(P>0.05)$. These results are similar to soybean (116\%) [22], but higher than those reported in other beans $[29,43,46,47]$. The high values of this property can be attributed to flexible protein molecules, which reduce surface tension and diffuse more quickly at the air-water interface, encapsulating air particles and thus favoring the formation of foam [48]. With respect to FS, significant differences $(P<0.05)$ were recorded among the six isolates evaluated (Table 2), with the highest value in the Boruta variety (93.9\%) and lowest value in Borlu variety (91.9\%). The results for FS were similar to those reported for L. angustifolius protein isolates [36] and higher than those reported for soy protein isolates [39]. When the foam stability values do not differ greatly from each other, it may be due to the ability to form a cohesive viscoelastic film via intermolecular interactions [49]. According to the study of Adebowale et al. [49], the better stability of the foams might be attributed to formation of stable molecular layers in the acidic $\mathrm{pH}$ range. However, within food systems, foams are complex systems, including different phases such as a mixture of gases subdivided at solids, liquids, and multicomponent solutions of water, polymers, and surfactants which make necessary studies in a wide range of $\mathrm{pH}$ values [50].

3.2.5. Gelling Minimum Concentration (GMC). The proteins are efficient gelling agents. A gel can be defined as an intermediate state between solid and liquid. Several factors influence gel formation, such as the protein size, molecular weight, amino acid composition, $\mathrm{pH}$, and interaction with other components, since large molecules form extensive networks by cross-linking in three dimensions and also by the flexibility and ability of the proteins to undergo denaturation. The results obtained for GMC show that the protein isolates of the different lupine varieties need a minimum concentration of protein that ranged from $10 \%$ (Boregine) up to $12 \%$ (Probor) in order to form a stable gel (Table 2). The results are similar to those found in the literature for L. angustifolius protein isolates [36] in common varieties [29, 47]. The GMC of Boregine was slightly better than soybean protein isolate (10\%). However, it is observed that lentil [29] and lima beans [47] show higher gelling capacity (7\%), while other types of beans [43] have a less gelling capacity (15\%). These variations between the different legumes seem to be related to the content of globulins which have high ease of forming gels [50, 51]. Hence, protein isolates of Lupinus are particularly useful in preparing comminuted meat emulsion as reported by Uvarova and Barrera-Arellano [44].

\section{Conclusions}

The chemical composition of $L$. angustifolius flour showed a significant difference among the different varieties evaluated, with protein contents of $28.40 \%$ in Boruta and $36.61 \%$ in Probor. Functional properties such as nitrogen solubility and the indexes of emulsion activity and emulsion stability were affected by the $\mathrm{pH}$ of the medium. In general, all these were minimal at values near the isoelectric point of the proteins (pH 4-6) and reached their maximum values at acidic (2) and alkaline $\mathrm{pH}(10)$. The maximum solubility of the protein isolates $(99 \%)$ was observed at $\mathrm{pH}$ values of 2.0 and 10.0 without significant differences between varieties. Water-holding capacity showed significant differences between varieties, while oil holding capacity and foam formation were similar in all varieties.

\section{Conflicts of Interest}

The authors declare that there are no conflicts of interest regarding the publication of this paper.

\section{Acknowledgments}

The authors acknowledge the National Council of Science and Technology of Mexico that granted Scholarship 589981 to Antonio Hilario Lara-Rivera.

\section{References}

[1] H. Schumacher, H. M. Paulsen, A. E. Gau et al., "Seed protein amino acid composition of important local grain legumes Lupinus angustifolius L., Lupinus luteus L., Pisum sativum L. and Vicia faba L.," Plant Breeding, vol. 130, no. 2, pp. 156-164, 2011.

[2] M. Saastamoinen, M. Eurola, and V. Hietaniemi, "The chemical quality of some legumes, peas, fava beans, blue and white lupins and soybeans cultivated in Finland," Journal of Agricultural Science and Technology, vol. 3, no. 3, pp. 92-100, 2013.

[3] L. Lopez-Bellido and M. Fuente, "Lupin crop as an alternative source of protein," Advances in Agronomy, vol. 40, pp. 239-295, 1986. 
[4] C. I. Lizarazo, A.-M. Lampi, J. Liu, T. Sontag-Strohm, V. Piironen, and F. L. Stoddard, "Nutritive quality and protein production from grain legumes in a boreal climate," Journal of the Science of Food and Agriculture, vol. 95, no. 10, pp. 2053-2064, 2015.

[5] G. D. Hill, "The comparison of nutritive value of lupin seed," Nutrition Abstracts and Reviews, vol. 47, pp. 511-529, 1977.

[6] D. S. Petterson, "The use of lupins in feeding systems-review," Asian-Australasian Journal of Animal Sciences, vol. 13, no. 6, pp. 861-882, 2000.

[7] A. Sujak, A. Kotlarz, and W. Strobel, "Compositional and nutritional evaluation of several lupin seeds," Food Chemistry, vol. 98, no. 4, pp. 711-719, 2006.

[8] L. Yeheyis, C. Kijora, E. Van Santen, M. Wink, and K. J. Peters, "Sweet annual lupins (Lupinus spp.); their adaptability and productivity in different agro-ecological zones of Ethiopia," Journal of Animal Science Advances, vol. 2, no. 2, pp. 201-215, 2012.

[9] G. G. Fontanari, J. M. Martins, M. Kobelnik et al., "Thermal studies on protein isolates of white lupin seeds (Lupinus albus)," Journal of Thermal Analysis and Calorimetry, vol. 108, no. 1, pp. 141-148, 2012.

[10] M. Duranti, A. Consonni, C. Magni, F. Sessa, and A. Scarafoni, "The major proteins of lupin seed: Characterisation and molecular properties for use as functional and nutraceutical ingredients," Trends in Food Science \& Technology, vol. 19, no. 12, pp. 624-633, 2008.

[11] B. Vargas-Guerrero, P. M. García-López, A. L. Martínez-Ayala, J. A. Domínguez-Rosales, and C. M. Gurrola-Díaz, "Administration of Lupinus albus Gamma Conglutin $(\mathrm{C} \gamma)$ to $\mathrm{n} 5 \mathrm{STZ}$ Rats Augmented Ins-1 Gene Expression and Pancreatic Insulin Content," Plant Foods for Human Nutrition, vol. 69, no. 3, pp. 241-247, 2014.

[12] C. Patanè, E. Iacoponi, and S. A. Raccuia, "Physico-chemical characteristics, water absorption, soaking and cooking properties of some Sicilian populations of chickpea (Cicer arietinum L.)," International Journal of Food Sciences and Nutrition, vol. 55, no. 7, pp. 547-554, 2004.

[13] N. G. Vera, "Utilización de los derivados de cereales y leguminosas en la elaboración de productos cárnicos," Nacameh, vol. 1, no. 1, pp. 110-117, 2007.

[14] E. García, Modificaciones al sistema de clasificación climática de Köppen, 1998.

[15] AOAC, Official Methods of Analysis, Association of Official Analytical Chemists, Washington, DC, USA, 2000.

[16] J. Vioque, V. R. Sánchez, J. Pedroche, Y. M. del Mar, and F. Millán, "Obtención y aplicaciones de concentrados y aislados proteicos," Grasas y Aceites, vol. 52, no. 2, pp. 127-131, 2001.

[17] C. Martínez-Villaluenga, G. Urbano, J. M. Porres, J. Frias, and C. Vidal-Valverde, "Improvement in food intake and nutritive utilization of protein from Lupinus albus var. multolupa protein isolates supplemented with ascorbic acid," Food Chemistry, vol. 103, no. 3, pp. 944-951, 2007.

[18] S. O. Ogunwolu, F. O. Henshaw, H.-P. Mock, A. Santros, and S. O. Awonorin, "Functional properties of protein concentrates and isolates produced from cashew (Anacardium occidentale L.) nut," Food Chemistry, vol. 115, no. 3, pp. 852-858, 2009.

[19] X. Liu, L. Zhang, S. Wei, S. Chen, X. Ou, and Q. Lu, "Overoxidized polyimidazole/graphene oxide copolymer modified electrode for the simultaneous determination of ascorbic acid, dopamine, uric acid, guanine and adenine," Biosensors and Bioelectronics, vol. 57, pp. 232-238, 2014.
[20] C.-F. Chau, Y.-L. Huang, and M.-H. Lee, "In vitro hypoglycemic effects of different insoluble fiber-rich fractions prepared from the peel of Citrus sinensis L. cv. liucheng," Journal of Agricultural and Food Chemistry, vol. 51, no. 22, pp. 6623-6626, 2003.

[21] H.-G. Zheng, X.-Q. Yang, C.-H. Tang, L. Li, and I. Ahmad, "Preparation of soluble soybean protein aggregates (SSPA) from insoluble soybean protein concentrates (SPC) and its functional properties," Food Research International, vol. 41, no. 2, pp. 154$164,2008$.

[22] P. C.-K. Cheung and C.-F. Chau, "Changes in the dietary fiber (resistant starch and nonstarch polysaccharides) content of cooked flours prepared from three Chinese indigenous legume seeds," Journal of Agricultural and Food Chemistry, vol. 46, no. 1, pp. 262-265, 1998.

[23] M. Bähr, A. Fechner, K. Hasenkopf, S. Mittermaier, and G. Jahreis, "Chemical composition of dehulled seeds of selected lupin cultivars in comparison to pea and soya bean," LWT-Food Science and Technology, vol. 59, no. 1, pp. 587-590, 2014.

[24] A. de Luna-Jiménez, "Composición y procesamiento de la soya para consumo humano," Investigación y Ciencia de la Universidad Autónoma de Aguascalientes, vol. 15, no. 37, pp. 35-44, 2007.

[25] G. E. De Almeida Costa, K. Da Silva Queiroz-Monici, S. M. P. M. Reis, and A. C. De Oliveira, "Chemical composition, dietary fibre and resistant starch contents of raw and cooked pea, common bean, chickpea and lentil legumes," Food Chemistry, vol. 94, no. 3, pp. 327-330, 2006.

[26] Z.-U. Rehinan, M. Rashid, and W. H. Shah, "Insoluble dietary fibre components of food legumes as affected by soaking and cooking processes," Food Chemistry, vol. 85, no. 2, pp. 245-249, 2004.

[27] K. R. Sridhar and S. Seena, "Nutritional and antinutritional significance of four unconventional legumes of the genus Canavalia - A comparative study," Food Chemistry, vol. 99, no. 2, pp. 267-288, 2006.

[28] E. Marconi, S. Ruggeri, M. Cappelloni, D. Leonardi, and E. Carnovale, "Physicochemical, nutritional, and microstructural characteristic of chickpeas (Cicer arietinum L.) and common beans (Phaseolus vulgaris L.) following microwave cooking," Journal of Agricultural and Food Chemistry, vol. 48, no. 12, pp. 5986-5994, 2000.

[29] G. Y. Aguilera, Harinas Leguminosas deshidratadas: Caracterización Nutricional y valoración de sus propiedades tecnofuncionales [Tesis Doctoral], Universidad Autónoma de Madrid, Facultad de Ciencias, Departamento de Química Agrícola, 2009.

[30] J. Boye, F. Zare, and A. Pletch, "Pulse proteins: processing, characterization, functional properties and applications in food and feed," Food Research International, vol. 43, no. 2, pp. 414431, 2010.

[31] E. Lampart-Szczapa, P. Konieczny, M. Nogala-Kałucka, S. Walczak, I. Kossowska, and M. Malinowska, "Some functional properties of lupin proteins modified by lactic fermentation and extrusion," Food Chemistry, vol. 96, no. 2, pp. 290-296, 2006.

[32] R. Horax, N. S. Hettiarachchy, P. Chen, and M. Jalaluddin, "Preparation and characterization of protein isolate from cowpea (Vigna unguiculata L. Walp.)," Journal of Food Science, vol. 69, no. 2, pp. FCT114-FCT118, 2004.

[33] C.-F. Chau, P. C. K. Cheung, and Y.-S. Wong, "Functional properties of protein concentrates from three Chinese indigenous legume seeds," Journal of Agricultural and Food Chemistry, vol. 45, no. 7, pp. 2500-2503, 1997. 
[34] J. Porras-Saavedra, N. Guemez-Vera, J. L. Montañez-Soto, and M. Carmen, "Comparative study of functional properties of protein isolates obtained from three Lupinus species," Advances in Bioresearch, vol. 4, pp. 106-116, 2013.

[35] T. A. El-Adawy, E. H. Rahma, A. A. El-Bedawey, and A. F. Gafar, "Nutritional potential and functional properties of sweet and bitter lupin seed protein isolates," Food Chemistry, vol. 74, no. 4, pp. 455-462, 2001.

[36] H. Lqari, J. Vioque, J. Pedroche, and F. Millán, "Lupinus angustifolius protein isolates: Chemical composition, functional properties and protein characterization," Food Chemistry, vol. 76, no. 3, pp. 349-356, 2002.

[37] A. Fernández-Quintela, M. T. Macarulla, A. S. Del Barrio, and J. A. Martínez, "Composition and functional properties of protein isolates obtained from commercial legumes grown in northern Spain," Plant Foods for Human Nutrition, vol. 51, no. 4, pp. 331342, 1997.

[38] M. Kaur and N. Singh, "Characterization of protein isolates from different Indian chickpea (Cicer arietinum L.) cultivars," Food Chemistry, vol. 102, no. 1, pp. 366-374, 2007.

[39] T. S. Withana-Gamage, J. P. Wanasundara, Z. Pietrasik, and P. J. Shand, "Physicochemical, thermal and functional characterisation of protein isolates from Kabuli and Desi chickpea (Cicer arietinum L.): A comparative study with soy (Glycine max) and pea (Pisum sativum L.)," Journal of the Science of Food and Agriculture, vol. 91, no. 6, pp. 1022-1031, 2011.

[40] S. L. Rodríguez-Ambriz, A. L. Martínez-Ayala, F. Millán, and G. Dávila-Ortíz, "Composition and functional properties of Lupinus campestris protein isolates," Plant Foods for Human Nutrition, vol. 60, no. 3, pp. 99-107, 2005.

[41] J. Yu, M. Ahmedna, and I. Goktepe, "Peanut protein concentrate: Production and functional properties as affected by processing," Food Chemistry, vol. 103, no. 1, pp. 121-129, 2007.

[42] A. V. Carvalho, N. H. P. García, and J. Amaya-Farfán, "Physicochemical properties of the flour, protein concentrate, and protein isolate of the cupuassu (Theobroma grandiflorum Schum) seed," Journal of Food Science, vol. 71, no. 8, pp. S573-S578, 2006.

[43] K. O. Adebowale and O. S. Lawal, "Comparative study of the functional properties of bambarra groundnut (Voandzeia subterranean), jack bean (Canavalia ensiformis) and mucuna bean (Mucuna pruriens) flours," Food Research International, vol. 37, no. 4, pp. 355-365, 2004.

[44] M. L. Uvarova and D. Barrera-Arellano, "Efecto de la lipofilización sobre las propiedades funcionales de la harina de palmist (Elaeis guineensis)," Grasas y Aceites, vol. 56, no. 1, pp. $1-8,2005$.

[45] F. H. Brishti, S. K. S. Zarei, M. R. Ismail-Fitry, R. Shukri, and N. Saari, "Evaluation of the functional properties of mung bean protein isolate for development of textured vegetable protein," International Food Research Journal, vol. 24, no. 4, pp. 15951605, 2017.

[46] L. Chel-Guerrero, V. Pérez-Flores, D. Betancur-Ancona, and G. Dávila-Ortiz, "Functional properties of flours and protein isolates from Phaseolus lunatus and Canavalia ensiformis seeds," Journal of Agricultural and Food Chemistry, vol. 50, no. 3, pp. 584-591, 2002.

[47] E. Sangronis, "Propiedades funcionales de las harinas de leguminosas (Phaseolus vulgaris y Cajan cajan) germinadas," Interciencia, vol. 29, no. 2, pp. 80-85, 2004.

[48] R. E. Aluko and R. Y. Yada, "Structure-function relationships of cowpea (Vigna unguiculata) globulin isolate: influence of $\mathrm{pH}$ and $\mathrm{NaCl}$ on physicochemical and functional properties," Food Chemistry, vol. 53, no. 3, pp. 259-265, 1995.

[49] Y. A. Adebowale, I. A. Adeyemi, and A. A. Oshodi, "Functional and physicochemical properties of flours of six Mucuna species," African Journal of Biotechnology, vol. 4, no. 12, pp. 14611468, 2005.

[50] S. K. Sathe and D. K. Salunkhe, "Functional properties of the great northern bean (Phaseolus vulgaris L.) proteins: emulsion, foaming, viscosity, and gelation properties," Journal of Food Science, vol. 46, no. 1, pp. 71-81, 1981.

[51] S. K. Sathe, S. S. Deshpande, and D. K. Salunkhe, "Functional properties of lupin seed (Lupinus mutabilis) proteins and protein concentrates," Journal of Food Science, vol. 47, no. 2, pp. 491-497, 1982. 

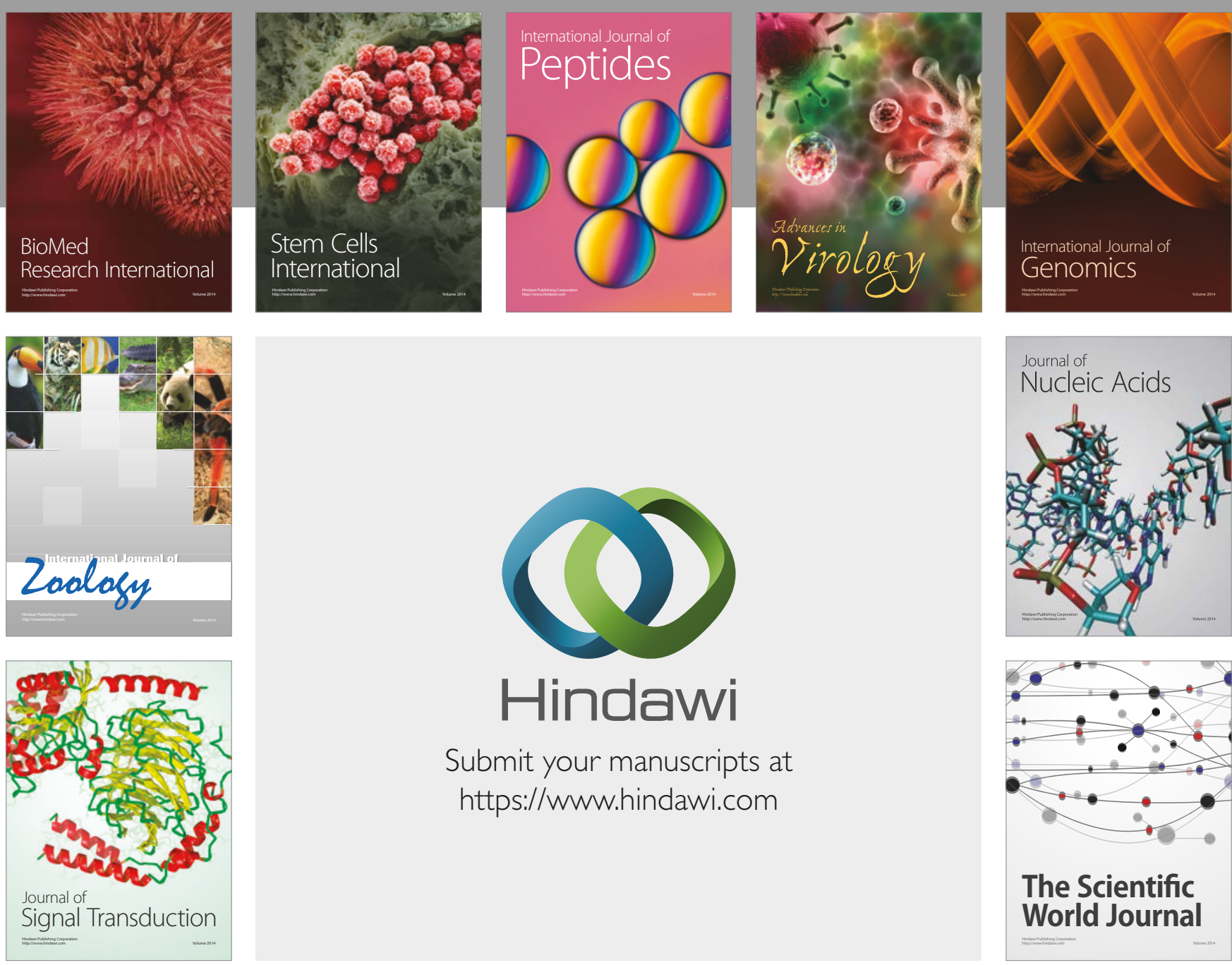

Submit your manuscripts at

https://www.hindawi.com
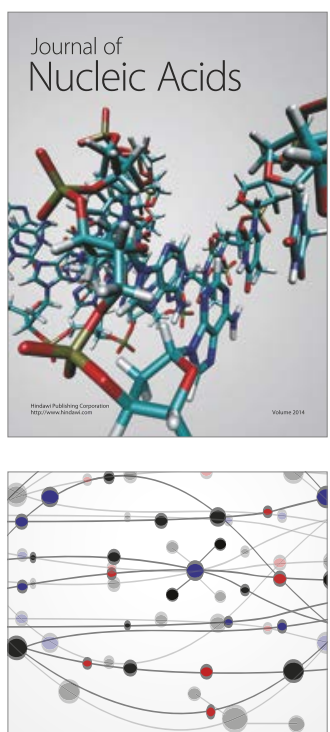

The Scientific World Journal

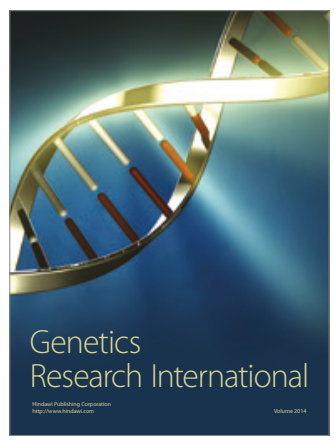

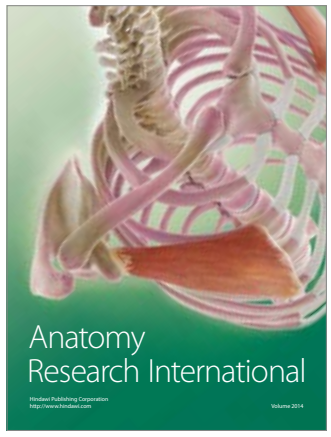

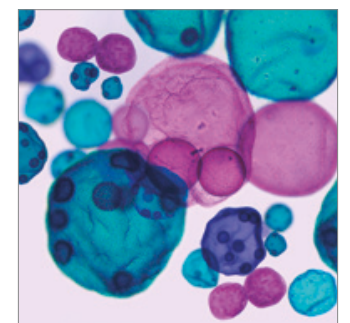

International Journal of Microbiology
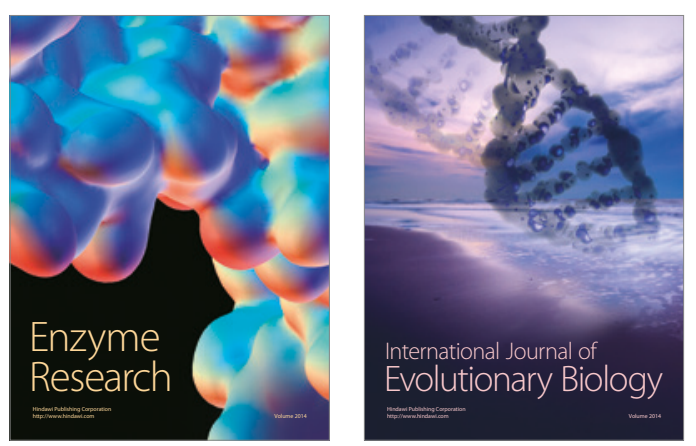
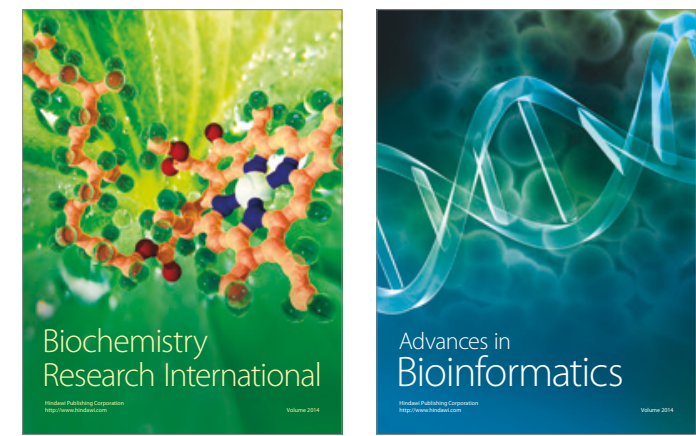

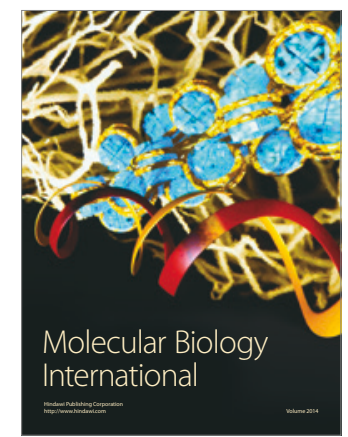

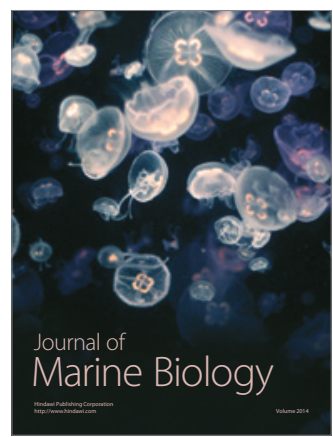

